\title{
Sexism in adolescence: parenting styles, division of housework, prosocial behaviour and aggressive behaviour / Sexismo en la adolescencia: estilos de crianza, división de tareas domésticas, conducta prosocial y agresividad
}

\author{
Elisabeth Malonda, Ana Tur-Porcar \& Anna Llorca
}

To cite this article: Elisabeth Malonda, Ana Tur-Porcar \& Anna Llorca (2017) Sexism in adolescence: parenting styles, division of housework, prosocial behaviour and aggressive behaviour / Sexismo en la adolescencia: estilos de crianza, división de tareas domésticas, conducta prosocial y agresividad, Revista de Psicología Social, 32:2, 333-361, DOI: $\underline{10.1080 / 02134748.2017 .1291745}$

To link to this article: http://dx.doi.org/10.1080/02134748.2017.1291745

Published online: 02 Mar 2017.

Щ Article views: 241
Submit your article to this journal $\sqsubset$ 


\title{
Sexism in adolescence: parenting styles, division of housework, prosocial behaviour and aggressive behaviour / Sexismo en la adolescencia: estilos de crianza, división de tareas domésticas, conducta prosocial y agresividad
}

\author{
Elisabeth Malonda, Ana Tur-Porcar, and Anna Llorca \\ Universitat de València \\ (Received 3 February 2016; accepted 7 September 2016)
}

\begin{abstract}
The aim of this study was to identify which factors were the best predictors of sexist attitudes. To achieve this aim, two groups of variables were analysed. The first group consisted of variables relating to parenting styles and the division of housework. The second group consisted of personal factors related to prosocial behaviour and physical and verbal aggression. The sample was made up of 732 adolescents aged 12-14 from Valencia (Spain). The analysis was conducted separately for boys and girls. Correlation analyses and multiple linear regression analyses were conducted on each subsample. The results show that the division of housework and parenting styles were related to sexist attitudes. This connection was especially strong for the division of housework according to traditional gender roles, which was found to lead to hostile and benevolent sexist attitudes. The results also showed that prosocial and aggressive behaviours were correlated with sexist attitudes. The results varied by gender. The findings of this research have implications for the prevention of sexist attitudes.
\end{abstract}

Keywords: physical and verbal aggression; prosocial behaviour; housework; benevolent sexism; hostile sexism

Resumen: El propósito de este estudio fue identificar los factores predictores de las actitudes sexistas en dos grupos de variables. Un grupo relacionado con los estilos de crianza y la división de tareas domésticas. El segundo relacionado con los factores personales de conducta prosocial y agresividad. La muestra estuvo compuesta por 732 adolescentes de entre 12-14 años de Valencia (España). Se realizó el análisis para chicos y chicas por separado. Los análisis de correlación y de regresión lineal múltiple se realizaron en cada submuestra. Los resultados indicaron que la división de tareas domésticas y

This paper was accepted by the last editorial team. / Este articulo fue aceptado por el anterior equipo editorial.

English version: pp. 333-345 / Versión en español: pp. 346-358

References / Referencias: pp. 358-361

Translated from Spanish / Traducción del español: Mary Black

Authors' Address / Correspondencia con las autoras: Ana Tur-Porcar, Departamento de Psicología Básica, Universitat de València, Avda. Blasco Ibáñez, 21, 46010 Valencia, España. Email: ana.tur@uv.es 
los estilos de crianza estuvieron relacionados con las actitudes sexistas. Esta conexión fue especialmente fuerte para la división de tareas según los roles de género tradicionales. Se observó que esto condujo a actitudes sexistas hostiles y benevolentes. Los resultados también mostraron que la conducta prosocial y la agresiva estaban correlacionadas con las actitudes sexistas. Los resultados variaron según el sexo. Los hallazgos de este estudio tienen implicaciones para la prevención de actitudes sexistas.

Palabras clave: agresión física y verbal; conducta prosocial; tareas domésticas; sexismo benevolente; sexismo hostil

Recent decades have witnessed a surge in research into sexism, yet we still know very little about the factors that explain the acceptance of sexism in modern society (Hart, Hung, Glick, \& Dinero, 2012). Sexism is rooted in social structures, so modern theoreticians of social role (Wood \& Eagly, 2010) and social domination theory (Sidanius \& Pratto, 2004) suggest that gender roles, which are associated with specific gender expectations and behaviours, consolidate sexist attitudes within adolescents (Bandura, 2011).

Wood and Eagly (2010) found that the division of housework determines gender stereotypes and gender differences, as well as sexist attitudes (Poeschl, Pinto, Múrias, Silva, \& Ribeiro, 2006). Furthermore, Garaigordobil and Aliri (2012) found a relationship between parenting styles and sexist attitudes, primarily the permissive or indulgent style. On the other hand, relationships between sexism and violence have been widely found, primarily gender violence and harassment (Buchanan, Settles, Hall, \& O'Connor, 2014; Expósito, Herrera, Moya, \& Glick, 2010; Yamawaki, Ostenson, \& Brown, 2009) and peer bullying (Ovejero, Yubero, Larrañaga, \& Navarro, 2013). However, to date the relationships between sexism and prosocial behaviour have not been analysed.

In this study, we seek to research the ties between adolescent sexist attitudes (both hostile and benevolent) and two kinds of factors: (a) personal factors, via prosocial behaviour and physical and verbal aggressive behaviour; and (b) family environment factors, via parenting styles and the division of housework by gender.

In any event, we should deepen our analysis of sexism in order to expand our knowledge of the development of sexist attitudes in adolescents so we can establish intervention programmes. This stage is when adolescent boys and girls are constructing their identities and understanding the injustice entailed in sexism (Glick \& Hilt, 2000).

\section{Hostile sexism (HS), benevolent sexism (BS) and sex differences in adolescence}

The ambivalent sexism theory (Glick \& Fiske, 1996; Lee, Fiske, \& Glick, 2010) encompasses two kinds of sexist attitudes: hostile and benevolent. HS is open, visible and explicit, while BS is subtle and invisible. BS seeks to help and protect women just because they are women. Both forms of sexism serve to legitimize traditional gender roles (Brandt, 2011; Chen, Fiske, \& Lee, 2009; Shnabel, BarAnan, Kende, Bareket, \& Lazar, 2016). 
It has repeatedly been proven that human societies are organized into groups established by social hierarchies (Wood \& Eagly, 2010), which leads to an imbalanced division of labour. This imbalance of labour pushes men into the public sphere and relegates women to the private sphere, which spurs the development of sexist attitudes.

Furthermore, cognitive social theory (Bandura, 2011) has shown that boys and girls watch the asymmetrical power relations around them through either real or symbolic models. These models are then internalized in childhood and adolescence. The need boys and girls feel to support a stable image of themselves encourages them to consolidate gender stereotypes (Glick \& Hilt, 2000).

In any event, it has been proven that sex can affect sexist attitudes in adolescents. Glick et al. (2004) found that boys earned higher scores than girls especially in HS, in a study on adolescents from 16 countries in Latin America, the Middle East, Europe and Australasia. The same results have been found in Spain (De Lemus, Moya, \& Glick, 2010; Montañés, Megías, De Lemus, \& Moya, 2015). However, in BS the results are contradictory. Some studies have found higher levels of BS in boys (Rodríguez, Lameiras, Carrera, \& Faílde, 2010), while others have found no significant differences between boys and girls (De Lemus et al., 2010; Glick et al., 2004; Montañés et al., 2015).

BS tends to be more accepted than HS (Napier, Thorisdottir, \& Jost, 2010) and exerts a considerable influence over lowering women's resistance to gender inequality (Becker \& Wright, 2011; Hammond \& Sibley, 2011; Napier et al., 2010). Women's support of BS plays a particularly important role in maintaining gender inequality (Napier et al., 2010).

These results may be due to the equation of HS with discrimination, while BS manages to neutralize efforts towards social changes because it is embraced by women (Becker \& Wright, 2011; Hammond, Sibley, \& Overall, 2014).

\section{The social context in Spain and the family environment}

Evolution in Spanish society has managed to leave perceptions about gender stereotypes that are apparently open and similar to those found in other countries, like the USA (Glick et al., 2004; López-Zafra \& García-Retamero, 2012). These perceptions directly affect youth (INJUVE, 2012b). There is a strong desire among adolescents and youth to defend equality as a guiding principle of human development. However, adolescent girls continue to do more housework than boys. Therefore, a traditional cultural sexism governs family organization, which causes gender inequality in the division of housework (INJUVE, 2012a) that in turn determines gender stereotypes and differences (Wood \& Eagly, 2010). On the other hand, the same Institute of Youth (INJUVE, 2012a) confirms that the family is the most important institution for Spanish youth. Therefore, it has been observed that the family and parenting styles play an essential role in conveying values, gender roles and sexist attitudes (Garaigordobil \& Aliri, 2012). Parenting styles set the rules of household coexistence which guide the development of children. A more inductive parenting style based on support and communication 
and coherent disciplinary rules helps children to develop soundly. This style has been called authoritative or coherent (Barnhart, Raval, Jansari, \& Raval, 2013). To the contrary, a more punitive parenting style based on negative psychological control of the child has been associated with problems of aggressive behaviour and emotional instability (Tur-Porcar, Mestre, Samper, \& Malonda, 2012).

\section{Personal factors}

In the past decade, research has related sexism to personal factors, both emotional and behavioural (De Lemus, Castillo, Moya, Padilla, \& Ryan, 2008). It has been shown that sexism is linked to violence and asymmetrical power relations (Expósito et al., 2010; Ovejero et al., 2013; Yamawaki et al., 2009).

In this study, sexism will be related to aggressive behaviour. Aggressive behaviour is meant as a lighter kind of violence with two fundamental forms of expression: physical and verbal (Furlong \& Smith, 1994). Physical aggression means a confrontation between two people (hitting), while verbal aggression alludes to the aggressive use of language (insults) (Björkqvist, 1994).

To date, the relationship between sexist attitudes and prosocial behaviour has not been studied. By prosocial behaviour we mean voluntary behaviour whose purpose is to help others and promote harmonious relationships with others (Bergin, Talley, \& Hamer, 2003). From this perspective, it would be worthwhile to ascertain the connections between prosocial behaviour and sexist attitudes. When boys and girls are likely to avoid aggressive behaviours and act more prosocially, they usually have better social relations (Valiente et al., 2011). Furthermore, prosocial behaviour can actually neutralize aggressive behaviour (Eisenberg et al., 2005).

\section{Objectives and hypotheses}

This study has four objectives. The first is to analyse the sex differences in HS, $\mathrm{BS}$, prosocial behaviour and aggressive behaviour and parenting style factors in adolescents. The second is to study the relationships between HS and BS and the variables mentioned. The third is to analyse the division of housework perceived by the adolescents. The fourth is to examine the weight of personal and family factors in the development of HS and BS in boys and girls. With these objectives, we seek to analyse which variables are predictors of sexism.

The model defined is the following (Figure 1).

We posited the following hypotheses:

Hypothesis 1: We expect boys to score somewhat higher in aggressive behaviour (Campbell, 2006) and on HS than girls (De Lemus et al., 2010), while girls are expected to score higher in prosocial behaviour (Carlo, Mestre, Samper, Tur, \& Armenta, 2010). In contrast, boys and girls will show similar scores on BS (De Lemus et al., 2010).

Hypothesis 2: Parenting styles will be related to sexist attitudes. A parenting style based on support/communication and permissiveness or indulgence will be 


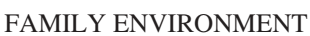

PERSONAL FACTORS

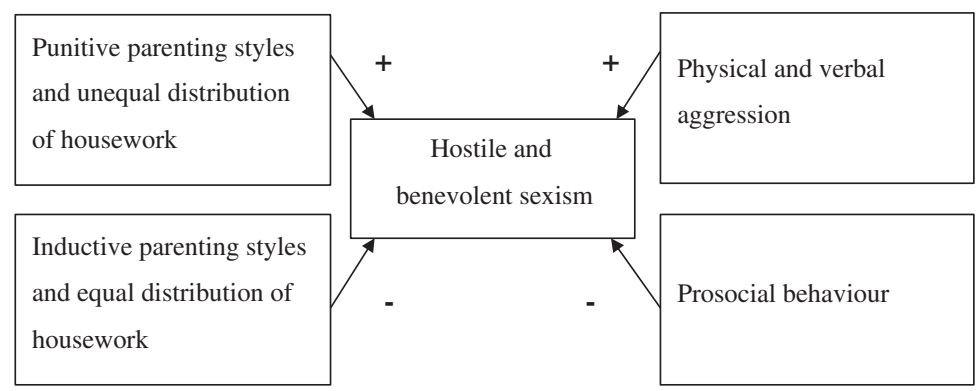

Figure 1. The model tested.

negatively related to sexist attitudes (Garaigordobil \& Aliri, 2012), while a more punitive parenting style based on psychological control and negligence will be positively related to sexist attitudes.

Hypothesis 3: We expect to find an imbalanced division of housework in which girls will have more chores than boys (Instituto de la Mujer, 2013; Williams, Park, Schmader, \& Cheryan, 2013).

Hypothesis 4: We expect family variables (division of housework, punitive parenting styles) to weigh more heavily in the development of HS and BS than personal variables (prosocial behaviour and aggressive behaviour), with division of housework being the strongest predictor (Bandura, 2011; Sidanius \& Pratto, 2004; Wood \& Eagly, 2010).

\section{Method}

\section{Participants}

A total of 732 students from compulsory secondary education (abbreviated ESO in Spanish) from seven public and two publicly-subsidized private schools in the Valencia metropolitan area (Spain) participated in the study, out of a total of 190,000 ESO students in the entire region of Valencia. They are aged 12 to 14 $(M=12.93, S D=0.946) ; 47.4 \%$ are boys, $52.6 \%$ are girls; and $73.5 \%$ of the adolescents live with both parents. Regarding the educational level of both parents, we found the following: university studies (fathers $29.5 \%$; mothers $29.2 \%$ ), secondary school (fathers $30.5 \%$, mothers $32.5 \%$ ), primary school (fathers $27.5 \%$, mothers $29 \%$ ) and no primary school education (fathers $6.8 \%$, mothers $5.3 \%$ ).

\section{Procedure}

The schools were chosen by a simple random sample bearing in mind their location within the Valencia metropolitan area and their classification as secondary schools. To choose them, we conducted a study by district in order to include 
all the zones of Valencia. This process enabled us to get a representative sample of Valencia made up of adolescents from different cultural environments.

This was a cross-sectional study. After securing authorization from the schools and the adolescents' parents or legal guardians, they filled out the questionnaires in their classrooms. The sessions lasted approximately 50 minutes. Participation was voluntary, anonymous and confidential. The ethical principles defined for this kind of study were followed. The students received the instructions and were accompanied by a trained researcher. Finally, the data were processed using SPSS 19.

\section{Instruments}

Inventory of ambivalent sexism for adolescents (Glick \& Fiske, 1996; Spanish version by De Lemus et al., 2008)

This is comprised of 20 items grouped into two dimensions: HS (e.g., 'Boys should control the people with whom their girlfriends interact') and BS (e.g., 'Girls should be loved and protected by boys'). Each item has six response alternatives ( $1=$ 'strongly disagree'; $6=$ 'strongly agree'). The Cronbach alphas were: HS $\alpha=.85$; BS $\alpha=.80$.

Parenting styles (Schaefer, 1965; Spanish version by Tur-Porcar, Mestre, \& Llorca, 2015)

This evaluates parents' attitudes towards parenting according to their children's vantage point via 38 items. They come with three alternatives: 'never', 'sometimes' and 'always'. There are four factors: (1) support and communication, referring to the perception of emotional support and affection (e.g., 'They like to talk with me about the news'); (2) psychological control, dealing with intrusive control and a negative evaluation of the children (e.g., 'They want to control everything I do'); (3) permissiveness, which addresses parents' tendency to allow their children to do what they want, ignoring the rules (e.g., 'They let me go out whenever I want'); and (4) negligence, which refers to parents' neglect of their parental responsibilities (e.g., 'They forget to give me things I need'). Cronbach alphas: support and communication $\alpha=.85$, psychological control $\alpha=.73$, negligence $\alpha=.71$ and permissiveness $\alpha=.65$.

Prosocial behaviour (Caprara \& Pastorelli, 1993; adaptation by Tur-Porcar, 2003) Through its 15 items it evaluates helpful, trusting and kind behaviours. It comes with three response choices ('often', 'sometimes' or 'never'). Examples of items: 'I try to help others', 'I'm kind'. Cronbach alpha $=.74$.

Physical and verbal aggression (Caprara \& Pastorelli, 1993; Spanish version by Del barrio, Moreno, \& López, 2001)

This evaluates the conduct of harming others, both physically and verbally, as a mild form of violence (Furlong \& Smith, 1994). It contains 20 items with three 
response choices ('often', 'sometimes' or 'never'). Examples of items include: 'I talk badly about my classmates', 'I hit my classmates', 'I trip my classmates' and 'I insult my classmates'. The Cronbach's alpha is .70.

The division of housework was based on three items: (1) 'My mother does most of the housework and my father only does a bit'; (2) 'My father has responsibilities outside the home and my mother takes care of the housework'; (3) 'Among siblings of the opposite sex, the girls have more responsibility at home than the boys'. The responses are dichotomous.

\section{Results}

\section{Differences according to sex}

To ascertain the differences among the participants by sex, we performed a one-factor analysis of variance (ANOVA) with the variables HS, BS, prosocial behaviour and aggressive behaviour, and the parents' parenting styles (Table 1). The ANOVAs confirmed significant differences in HS $\left(F=269.53, p<.01 ; \eta^{2}=.27\right)$ and in BS $\left(F=3.62, p<.05 ; \eta^{2}=.05\right)$. In both cases the boys showed higher scores. The effect size was large for HS and small for BS (Bray \& Maxwell, 1985).

Regarding the personal variables, we found significant differences in prosocial behaviour $\left(F=33.68, p<.001 ; \eta^{2}=.04\right)$ (girls showed higher scores) and in aggressive behaviour $\left(F=34.17, p<.001 ; \eta^{2}=.04\right)$, where the boys scored higher. In both cases, the effect size was medium.

Regarding parenting styles, the ANOVAs confirmed that boys perceive greater permissiveness $\left(F=4.62, p<.05 ; \eta^{2}=.06\right)$, higher negligence $(F=7.04, p<.01$; $\left.\eta^{2}=.01\right)$ and less psychological control $\left(F=11.54, p<.01 ; \eta^{2}=.01\right)$ compared to girls. In all three cases, the effect size was small. There were no significant differences between boys and girls in the support and communication factor $(F=.04, p>.05)$.

A descriptive analysis of the items related to the division of housework indicates that almost one-third of the sample attributed more household

Table 1. Comparison of the means of the variables studied by sex.

\begin{tabular}{|c|c|c|c|c|c|c|}
\hline & \multicolumn{2}{|c|}{ Boys } & \multicolumn{2}{|c|}{ Girls } & \multirow[b]{2}{*}{$F$} & \multirow[b]{2}{*}{$\eta^{2}$} \\
\hline & $M$ & $S D$ & $M$ & $S D$ & & \\
\hline 1. Hostile $\mathrm{s}$ & 3.79 & 1.09 & 2.55 & 0.95 & $269.53 * *$ & .27 \\
\hline 2. Benevolent sexism & 4.27 & 1.08 & 4.11 & 1.15 & $3.62 *$ & .0 \\
\hline 3. Prosocial behaviour & 2.43 & 0.29 & 2.55 & 0.26 & $33.69 * *$ & .04 \\
\hline 4. Physical and verbal aggressive behaviour & 1.49 & 0.36 & 1.35 & 0.29 & $34.17 * *$ & .04 \\
\hline 5. Support and communication ${ }^{(1)}$ & 4.52 & 1.31 & 4.48 & 1.21 & 0.04 & _ \\
\hline 6. Psychological control ${ }^{(2)}$ & 2.24 & 1.29 & 3.93 & 1.16 & $11.54 * *$ & .06 \\
\hline 7. Permissiveness ${ }^{(3)}$ & 3.23 & 1.73 & 3.01 & 1.67 & $4.62 *$ & .01 \\
\hline 8. Negligence ${ }^{(4)}$ & 2.60 & 1.50 & 2.31 & 1.24 & $7.04 * *$ & .01 \\
\hline
\end{tabular}

Note: **.01 (bilateral); *.05 (bilateral); ${ }^{(1)}$ Support and communication (Mother x Father); (2) Psychological control (Mother x Father); ${ }^{(3)}$ Permissiveness (Mother x Father); ${ }^{(4)}$ Negligence (Mother x Father). 
responsibilities to the mother and that the father was given the role of helper. The affirmative responses (in percentages) by items are: 'My mother does most of the housework and my father only does a bit' (71.7\%); 'My father has responsibilities outside the home and my mother takes care of the housework' $(62.0 \%)$; 'Among siblings of the opposite sex, the girls have more responsibility at home than the boys' $(47.3 \%)$. In this latter case, the perceptions of boys and girls regarding the division of housework among adolescents are more balanced.

\section{Correlations analyses among variables analysed}

In HS, the Pearson's correlational analysis showed positive relationships with the imbalanced division of housework in girls and boys, where mothers and daughters have a heavier burden. Furthermore, in boys HS has been positively related to negligence and permissiveness and in girls with permissiveness and psychological control. Likewise, in both boys and girls, positive relationships appeared between HS and aggressive behaviour and negative relationship between HS and prosocial behaviour (Table 2).

Regarding BS, positive relationships appeared with the unequal division of housework in both boys and girls. It was also associated with the parenting factors of negligence (in boys) and psychological control and permissiveness (in girls) (Table 2).

\section{Variables predicting $\mathrm{HS}$ and $\mathrm{BS}$}

Finally, four multiple linear regressions were performed by steps to analyse the variables predicting HS and BS in boys and girls. The dependent variables are HS and BS. The independent variables are the family environment variables and the personal variables studied. The values of the variance inflation factor (VIF) (Table 3) are around 1 in all cases (Kleinbaum, Kupper, \& Muller, 1988), indicating that there are no collinearity problems.

Table 3 shows that in HS and BS the division of housework is more important than the personal variables of prosocial behaviour and aggressive behaviour. The variables predicting HS are: in boys, they revolve around the division of housework and negligence $\left(R^{2}=.23\right)$, while in girls they centre positively on the division of housework and negatively on prosocial behaviour $\left(R^{2}=.17\right)$.

Regarding BS, in boys the variables that explain their sexist attitudes are related to the division of housework and negligence, both of them positively $\left(R^{2}=.11\right)$. In girls, the predictive variables continue to be related to the division of housework plus psychological control, both positively. These variables explain $15.5 \%$ of the variance $\left(R^{2}=.15\right)$.

\section{Discussion}

The core objective of this study was to analyse the importance of family environment factors (division of housework and parenting styles) and the personal factors 


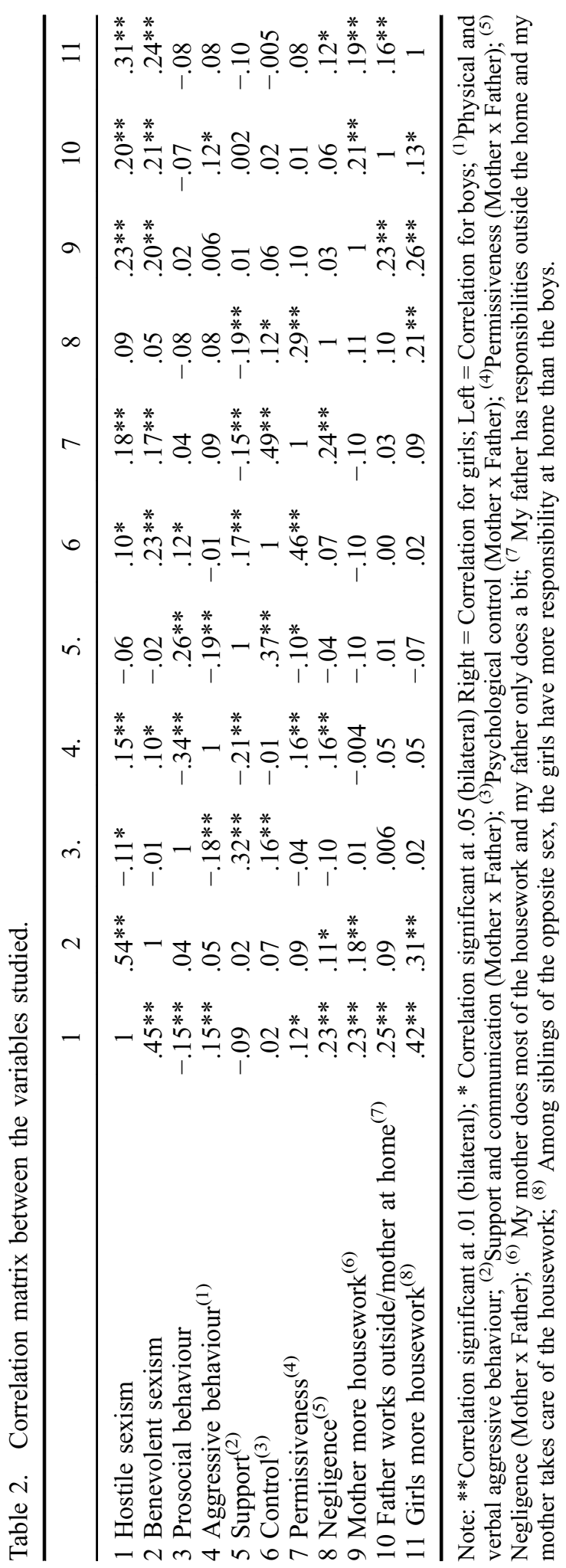


Table 3. Multiple linear regression analysis.

\begin{tabular}{|c|c|c|c|c|c|c|c|}
\hline & $R^{2}$ & $B$ & $\begin{array}{l}\text { Standard } \\
\text { error }\end{array}$ & Beta & $T$ & Sig. & $V I F$ \\
\hline \multicolumn{8}{|l|}{ Hostile sexism } \\
\hline \multicolumn{8}{|l|}{ Boys } \\
\hline Constant & & 1.54 & .33 & & 4.57 & .000 & \\
\hline Girls more housework $^{(1)}$ & .19 & 0.84 & .13 & .38 & 6.35 & .000 & 1.06 \\
\hline $\begin{array}{l}\text { Father works outside/mother at } \\
\text { home }^{(2)}\end{array}$ & .21 & 0.35 & .13 & .15 & 2.60 & .010 & 1.01 \\
\hline Negligence $^{(3)}$ & .23 & 0.34 & .14 & .14 & 2.34 & .020 & 1.04 \\
\hline \multicolumn{8}{|l|}{ Girls } \\
\hline Constant & & 1.86 & .61 & & 3.03 & .003 & \\
\hline Girls more housework & .10 & 0.49 & .11 & .25 & 4.36 & .000 & 1.06 \\
\hline Mother more housework & .13 & 0.35 & .12 & .16 & 2.83 & .005 & 1.06 \\
\hline Father works outside/mother at home & .16 & 0.30 & .11 & .15 & 2.64 & .009 & 1.05 \\
\hline Prosocial behaviour & .17 & -0.42 & .20 & -.11 & -2.04 & .042 & 1.01 \\
\hline \multicolumn{8}{|l|}{ Benevolent sexism } \\
\hline \multicolumn{8}{|l|}{ Boys } \\
\hline Constant & & 3.21 & .21 & & 14.83 & .000 & \\
\hline Girls more housework & .09 & 0.61 & .13 & .28 & 4.46 & .000 & 1.04 \\
\hline Negligence & .11 & 0.09 & .04 & .13 & 2.07 & .000 & 1.04 \\
\hline \multicolumn{8}{|l|}{ Girls } \\
\hline Constant & & 1.73 & .38 & & 4.51 & .000 & \\
\hline Father works outside/mother at home & .07 & 0.49 & .13 & .21 & 3.70 & .000 & 1.05 \\
\hline Girls more housework & .11 & 0.41 & .13 & .18 & 3.12 & .002 & 1.05 \\
\hline Psychological control $^{(5)}$ & .14 & 0.14 & .05 & .16 & 2.89 & .004 & 1.00 \\
\hline Mother more housework & .15 & 0.30 & .14 & .12 & 2.08 & .038 & 1.06 \\
\hline
\end{tabular}

Note: ${ }^{(1)}$ Among siblings of the opposite sex, the girls have more responsibility at home than the boys; ${ }^{(2)}$ My father has responsibilities outside the home and my mother takes care of the housework; ${ }^{(3)}$ Negligence (Mother x Father); ${ }^{(4)}$ My mother does most of the housework and my father only does a bit; ${ }^{(5)}$ Psychological control (Mother x Father).

of aggressive behaviour and prosocial behaviour in predicting HS and BS in young adolescent boys and girls.

The results showed that both HS and BS are related to an unequal distribution of housework, which is primarily done by women. Likewise, sexism is also related to more punitive parenting such as psychological control and negligence, in addition to permissiveness (Hypothesis 2). Therefore, the family environment, through the distribution of housework coupled with more punitive parenting (psychological control and negligence) has supported hostile and benevolent sexist attitudes (Hypothesis 4).

Parental models are visible in children. Parents send messages and ask for help to do housework; hence their requests can help consolidate traditional gender roles (Wood \& Eagly, 2010).

The analysis shows that adolescent boys are more sexist (hostile and benevolent) than girls of the same age (Montañés et al., 2015; Rodríguez et al., 2010) (Hypothesis 1). Both kinds of sexism reinforce gender-unbalanced social 
structures (Glick \& Hilt, 2000; Wood \& Eagly, 2010). These results corroborate the fact that the uneven distribution of housework may contribute to perpetuating asymmetrical relations, which originate in a patriarchal structure based on the division of roles (Chen et al., 2009). The results in this study are consistent with other studies performed with adolescents from the USA, Sweden and Spain (De Lemus et al., 2008; Zakrisson, Anderzén, Lenell, \& Sandelin, 2012). Furthermore, favouring males gives them power over women (De Lemus et al., 2008), which may have counterproductive effects on the population and a negative impact on the education and professional development of females (Fisher \& Anderson, 2012).

On the other hand, there are positive relations between HS and BS and aggressive behaviour (Ovejero et al., 2013), and negative relations between HS and prosocial behaviour in both boys and girls. However, boys scored higher on aggressive behaviour, while girls scored higher on prosocial behaviour (Hypothesis 1). Thus, girls showed higher scores on attributes related to femininity (e.g., understanding or altruism). These differences reflect the duality of human existence, as girls are assigned communal attributes and boys agentic attributes (Wood \& Eagly, 2010). Nonetheless, we believe that it is positive to score highly on prosocial behaviour given its protective nature (Eisenberg et al., 2005), and that scores on this should be similar in both sexes. These results are in line with other studies that examine sex differences in prosocial behaviour (Carlo et al., 2010). Likewise, prosocial behaviour has been found to be predictive of HS in girls, acting negatively to protect HS.

Regarding the division of housework, almost three-quarters of the population claimed that mothers take on a higher burden. Among adolescents, this percentage decreases to one-half. The decline in the percentage in adolescence may reflect the evolution of Spanish society towards a more egalitarian model (Gartzia \& LópezZafra, 2014). These observations support the double workday of women, that is, at work and at home (public/private sphere).

Furthermore, the unbalanced division of housework, primarily assigning it to mothers and daughters, goes a long way towards predicting HS and BS in both boys and girls (Hypothesis 4). Therefore, this situation reinforces social inequality based on gender. The results are consistent with those of other studies which show that Spanish women have a heavy domestic burden, spending twice or three times the amount of time on these chores than men (Instituto de la Mujer, 2013). Therefore, it is essential to encourage the balanced division of family responsibilities in order to break with gender stereotypes, which are so closely tied to the survival of sexism. Even though BS is apparently more conciliatory, it is also more effective in perpetuating gender differences (Delacollette, Dumont, Sarlet, \& Dardenne, 2013).

A cross-cultural analysis indicates that the situation among Spanish adolescents does not differ much from other cultures. The balanced/imbalanced division of housework facilitates the transmission of models among adolescents, giving rise to sexist or egalitarian attitudes in different countries like the United States and Canada (Fisher \& Anderson, 2012; Williams et al., 2013). 
Regarding parenting styles, HS is related to a more punitive parenting style (psychological control and negligence) (Hypothesis 2). A punitive parenting style promotes little affection and communication (Barnhart et al., 2013). These results reinforce the findings of Garaigordobil and Aliri (2012), who found that an indulgent/permissive parenting style promotes less sexist attitudes. In our study, psychological control is a predictor of BS in girls and negligence is a predictor of both HS and BS in boys (Hypothesis 4).

The results confirm that the traditional roles and family discipline are more important in predicting sexist attitudes than personal variables like aggressive behaviour and prosocial behaviour (Hypothesis 4). In other words, the way both parents act promotes sexist attitudes. Likewise, the psychological control and negligence factors of both parents positively predict BS in adolescents.

The results also show the complexity of BS. Its positive nuances make it somewhat socially acceptable, even among women, who seek its protection. Despite this widespread acceptance, BS is a form of sexism which perpetuates social inequality (Becker \& Swim, 2011).

In summary, we can assume that the internal family dynamic and parenting styles are interrelated in such a way that the style of a more traditional family tends to be more authoritarian. Authoritarian and more punitive parenting leads to certain household rules and one-directional communication, from parents to children. These models are likely to keep the traditional role distribution based on gender. The males are assigned active roles outside the household to secure economic resources, while the females are expected to take on more communal roles as wives and mothers (Wood \& Eagly, 2010). Furthermore, BS in mothers can predict BS in daughters (Montañés et al., 2012).

Similar situations have been found in a recent study carried out in New Orleans (USA). Williams et al. (2013) showed that girls whose parents share the housework in a balanced fashion are less likely to have sexist attitudes.

The results show the need to hold workshops geared towards families that explain the value of family co-responsibility. It is essential to earmark resources that encourage coeducation from the gender perspective and that stimulate the equitable division of housework and gradually destroy the duality of human existence. By doing this, we would contribute to ensuring that both boys and girls develop their full potential without suffering from the limitations of gender stereotypes. Furthermore, the efficacy of interventions to lower sexist attitudes could be improved by training families and promoting more inductive and less punitive forms of discipline.

This study has several limitations. First, the data were collected via selfreporting by adolescents. In future studies, sexist attitudes of adolescents should be compared to the attitudes of their parents. This comparison could show the degree of affinity between parents and children, in addition to revealing the evolution of adolescents' attitudes towards this social phenomenon.

Secondly, this study has focused on early adolescence. Future studies could analyse sexism at different periods of adolescence and sexism in relation to the school setting and social relations with peers. For example, do peer abuse and 
victimization affect adolescents' sexist attitudes? Does the academic curriculum have any relationship with sexist attitudes? Do sexist attitudes promote the choice of more caring, feminized careers in adolescents?

Third, subsequent studies should observe sexist attitudes among peers. This knowledge is essential to understanding sexism between boys and girls. Furthermore, other personal factors like empathy or human values are relevant and may explain sexist attitudes as well. We are aware that studying the development of HS and BS has several implications for reducing gender inequalities (De Lemus et al., 2008); however, a change in attitude may not be enough to eradicate gender inequality due to recurring, unconscious sexism which is difficult to avoid.

Finally, another limitation is the cross-sectional nature of the study, which prevents us from establishing causal relationships. It seems logical, and the results support it, that an unequal distribution of housework and the parenting styles, that is, environmental factors, are essential to the development of sexist attitudes in early adolescence. 


\section{Sexismo en la adolescencia: estilos de crianza, división de tareas domésticas, conducta prosocial y agresividad}

En las últimas décadas ha surgido mucha investigación sobre el sexismo, con todo, aún se sabe poco sobre los factores que pueden explicar la aceptación del sexismo en la sociedad moderna (Hart, Hung, Glick, \& Dinero, 2012). El sexismo tiene sus raíces en las estructuras sociales, de ahí que los modelos teóricos de la teoría del rol social (Wood \& Eagly, 2010) y de la dominación social (Sidanius \& Pratto, 2004) planteen que los roles de género, asociados con expectativas y conductas específicas de género, consoliden las actitudes sexistas de los y las adolescentes (Bandura, 2011).

Wood y Eagly (2010) comprobaron que la división de tareas en el hogar determina los estereotipos de género y las diferencias de género, así como actitudes sexistas (Poeschl, Pinto, Múrias, Silva, \& Ribeiro, 2006). Además, Garaigordobil y Aliri (2012) han observado una relación entre estilos de crianza $\mathrm{y}$ actitudes sexistas, fundamentalmente el estilo permisivo o indulgente. Por otro lado, se ha comprobado ampliamente las relaciones del sexismo y la violencia, fundamentalmente la violencia de género y acoso (Buchanan, Settles, Hall, \& O’Connor, 2014; Expósito, Herrera, Moya, \& Glick, 2010; Yamawaki, Ostenson, \& Brown, 2009) y de bullying entre los pares (Ovejero, Yubero, Larrañaga, \& Navarro, 2013). Sin embargo, hasta el momento, no se han analizado las relaciones del sexismo y la conducta prosocial.

En este trabajo pretendemos investigar los vínculos entre las actitudes sexistas adolescentes (hostiles y benevolentes) y dos tipos de factores: (a) personales, a través de la conducta prosocial y la agresividad física y verbal y (b) el entorno familiar, a través de los estilos de crianza y la distribución de tareas domésticas en función del género.

De cualquier modo, conviene profundizar el análisis sobre el sexismo para ampliar el conocimiento sobre el desarrollo de las actitudes sexistas en la adolescencia de cara a establecer programas de intervención. En esta etapa, chicos y chicas adolescentes van construyendo su identidad y comprendiendo la injusticia que implica el sexismo (Glick \& Hilt, 2000).

\section{Sexismo hostil (SH), sexismo benevolente (SB) y las diferencias de sexo en la adolescencia}

La teoría del sexismo ambivalente (Glick \& Fiske, 1996; Lee, Fiske, \& Glick, 2010) comprende dos tipos de actitudes sexistas: hostil y benevolente. El SH es abierto, visible y explícito, mientras que el SB es sutil e invisible. El SB busca 
ayudar y proteger a las mujeres, por el hecho de serlo. Ambas formas de sexismo sirven para legitimar los roles tradicionales de género (Brandt, 2011; Chen, Fiske, \& Lee, 2009; Shnabel, Bar-Anan, Kende, Bareket, \& Lazar, 2016).

En reiteradas ocasiones se ha comprobado que las sociedades humanas están organizadas en grupos establecidos por jerarquías sociales (Wood \& Eagly, 2010), que provoca un reparto desequilibrado del trabajo. Este desequilibrio del trabajo impulsa a los hombres a la esfera pública y relega a las mujeres al ámbito privado, lo cual será un acicate para el desarrollo de las actitudes sexistas.

Además, la teoría social cognitiva (Bandura, 2011) ha demostrado que chicos y chicas van observando relaciones de poder asimétricas en su entorno, mediante modelos reales o simbólicos. Dichos modelos van interiorizándose en la infancia y adolescencia. La necesidad que sienten chicos y chicas de apoyar una imagen estable de sí mismos/as les anima a consolidar los estereotipos de género (Glick \& Hilt, 2000).

En cualquier caso, se ha demostrado que el sexo puede afectar a las actitudes sexistas en la adolescencia. Glick et al. (2004) comprobaron que los chicos obtuvieron mayores puntuaciones que las chicas, especialmente en $\mathrm{SH}$, en un estudio sobre adolescentes de 16 países de Latinoamérica, Oriente Medio, Europa y Australasia. En España se han obtenido los mismos resultados (De Lemus, Moya, \& Glick, 2010; Montañés, Megías, De Lemus, \& Moya, 2015). Sin embargo, en SB los resultados son contradictorios. De una parte, se han encontrado mayores niveles de SB en chicos (Rodríguez, Lameiras, Carrera, \& Faílde, 2010). De otra, no se han encontrado diferencias significativas entre chicos y chicas (De Lemus et al., 2010; Glick et al., 2004; Montañés et al., 2015).

El SB tiende a ser más aceptado que el SH (Napier, Thorisdottir, \& Jost, 2010) y ejerce una influencia notable a la hora de reducir la resistencia de las mujeres a la desigualdad de género (Becker \& Wright, 2011; Hammond \& Sibley, 2011; Napier et al., 2010). El respaldo de las mujeres al SB juega un papel particularmente importante en el mantenimiento de la desigualdad de género (Brandt, 2011).

Estos resultados pueden deberse a la identificación del SH con la discriminación, mientras que el SB al ser bien recibido por las mujeres llega a neutralizar los esfuerzos hacia los cambios sociales (Becker \& Wright, 2011; Hammond, Sibley, \& Overall, 2014).

\section{El contexto social español y el entorno familiar}

La evolución de la sociedad española ha logrado que las percepciones sobre los estereotipos de género sean aparentemente abiertas y similares a las de otros países, como USA (Glick et al., 2004; López-Zafra \& García-Retamero, 2012). Dichas percepciones afectan directamente a la juventud (INJUVE, 2012b). Entre jóvenes y adolescentes existe una amplia voluntad de defender la igualdad como principio rector para el desarrollo humano. Sin embargo, las chicas adolescentes continúan realizando más tareas domésticas que los chicos. Existe, pues, un sexismo cultural tradicional gobernando la organización familiar, que causa 
desigualdad de género en la división de tareas domésticas (INJUVE, 2012a) que determina estereotipos y diferencias de género (Wood \& Eagly, 2010). Por otra parte, el mismo Instituto de la Juventud (INJUVE, 2012a) confirma que la familia es la institución más importante para la juventud española. Así pues, se ha observado que la familia y la crianza juegan un papel fundamental en la trasmisión de valores, roles de género y actitudes sexistas (Garaigordobil \& Aliri, 2012). La crianza establece reglas de convivencia que guían el desarrollo de los hijos e hijas. Una crianza más inductiva, basada en apoyo y comunicación y normas disciplinarias coherentes, facilita el desarrollo adaptado de los hijos e hijas. Este estilo se ha denominado autoritativo o coherente (Barnhart, Raval, Jansari, \& Raval, 2013). Por el contrario, una crianza más punitiva, basada en el control psicológico negativo del hijo/a se ha relacionado con problemas de agresividad e inestabilidad emocional (Tur-Porcar, Mestre, Samper, \& Malonda, 2012).

\section{Factores personales}

En la última década, la investigación ha relacionado el sexismo con factores personales, de orden emocional y conductual (De Lemus, Castillo, Moya, Padilla, \& Ryan, 2008). Como se ha puesto de manifiesto el sexismo está unido a la violencia y a las relaciones asimétricas de poder (Expósito et al., 2010; Ovejero et al., 2013; Yamawaki et al., 2009).

En esta investigación se relacionará el sexismo con la agresividad. Se entiende como agresividad como una forma más leve de violencia con dos manifestaciones fundamentales, física y verbal (Furlong \& Smith, 1994). Por agresión física se refiere a una confrontación entre dos personas (golpear) y la verbal alude al uso agresivo a través del lenguaje (insultar) (Björkqvist, 1994).

Hasta el momento no se ha abordado la relación entre las actitudes sexistas y la conducta prosocial. Consideramos la conducta prosocial como una conducta voluntaria que tiene la finalidad de ayudar al otro y promueve relaciones armoniosas con los demás (Bergin, Talley, \& Hamer, 2003). Desde esta perspectiva, puede ser interesante conocer las conexiones de la conducta prosocial y las actitudes sexista. Cuando los chicos y chicas son propensos a evitar conductas agresivas y a actuar de forma más prosocial suelen mantener, en general, mejores relaciones sociales (Valiente et al., 2011). Además, la conducta prosocial ha llegado a neutralizar la conducta agresiva (Eisenberg et al., 2005).

\section{Objetivos e hipótesis}

Este estudio tiene cuatro objetivos. Primero, analizar las diferencias de sexo en $\mathrm{SH}, \mathrm{SB}$, conducta prosocial y agresividad y factores de crianza en la adolescencia. Segundo, estudiar las relaciones entre SH y SB y las variables mencionadas. Tercero, analizar el reparto de tareas domésticas percibido por los/las adolescentes. Cuarto, examinar el peso de los factores personales y del entorno familiar 

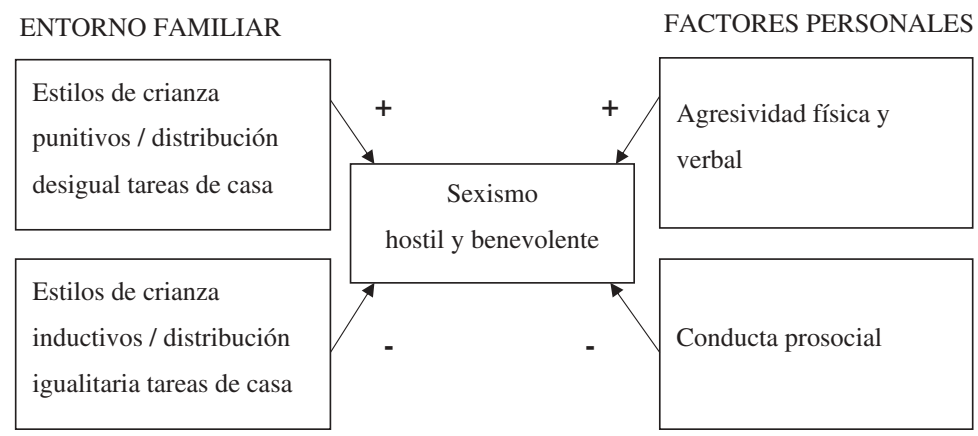

Figura 1. El model probado.

en el desarrollo del SH y SB en chicos y en chicas. Con ello pretendemos analizar qué variables son predictoras de sexismo.

El modelo definido es el siguiente (Figura 1).

Planteamos las siguientes hipótesis:

Hipótesis 1: Se espera que los chicos puntúen más alto en agresividad (Campbell, 2006) y en SH que las chicas (De Lemus et al., 2010), mientras que las chicas puntúen más alto en conducta prosocial (Carlo, Mestre, Samper, Tur, \& Armenta, 2010). En cambio, chicos y chicas tendrán puntuaciones similares en SB (De Lemus et al., 2010).

Hipótesis 2: Los estilos de crianza se relacionarán con las actitudes sexistas. Un estilo de crianza basado en apoyo/comunicación y permisividad o indulgencia se relacionarán negativamente con las actitudes sexistas (Garaigordobil \& Aliri, 2012) mientras que el estilo de crianza más punitivo, basado en el control psicológico y la negligencia se relacionarán positivamente.

Hipótesis 3: Se espera un reparto desequilibrado de las tareas domésticas. Las chicas tendrán más tareas que los chicos (Instituto de la Mujer, 2013; Williams, Park, Schmader, \& Cheryan, 2013).

Hipótesis 4: Se espera que las variables del entorno familiar (reparto de tareas domésticas y estilos de crianza punitivos) tengan más peso en el desarrollo de $\mathrm{SH}$ y SB, que las variables personales (conducta prosocial y agresividad), siendo la división de tareas domésticas el predictor más fuerte (Bandura, 2011; Sidanius \& Pratto, 2004; Wood \& Eagly, 2010). 


\section{Método}

\section{Participantes}

Han participado 732 estudiantes de la Educación Secundaria Obligatoria (ESO) (en la ESO en toda la Comunidad Valenciana hay unos 190,000 estudiantes) de siete escuelas públicas y dos concertadas del área metropolitana de Valencia (España). Tienen entre 12 y 14 años $(M=12.93, D T=0.946)$. De ellos, el $47.4 \%$ son chicos y el $52.6 \%$ chicas. El $73.5 \%$ de los adolescentes viven con ambos padres. Sobre el nivel educativo de ambos padres se ha observado lo siguiente: estudios universitarios (padres 29.5\%; madres 29.2\%), estudios secundarios (padres 30.5\%, madres 32.5\%), estudios primarios (padres $27.5 \%$, madres $29 \%$ ); y sin estudios primarios (padres $6.8 \%$, madres $5.3 \%$ ).

\section{Procedimiento}

La elección de los centros se ha realizado mediante un muestreo aleatorio simple, teniendo en cuenta su localización en el área metropolitana de Valencia y su clasificación como centros de secundaria. Para ello realizamos el estudio por distritos para incluir todas las zonas de Valencia. Este proceso ha permitido obtener una muestra representativa de Valencia, formada por adolescentes de diferentes entornos culturales.

Se trata de un estudio transversal. Previa autorización de los centros educativos y de los padres o tutores legales, los y las adolescentes fueron completando los cuestionarios en las mismas clases. Las sesiones duraron aproximadamente 50 minutos. La participación fue voluntaria, anónima y confidencial. Se siguieron los principios éticos definidos para este tipo de estudios. Los y las estudiantes recibieron las instrucciones y estuvieron acompañados por una profesional experta. Finalmente, los datos se procesaron a través del SPSS 19.

\section{Instrumentos}

Inventario de sexismo ambivalente para adolescentes (Glick \& Fiske, 1996; versión española por De Lemus et al., 2008)

Comprende 20 ítems agrupados en dos dimensiones: SH (e.g., 'Los chicos deben controlar con quien se relacionan sus novias') y SB (e.g., 'Las chicas deben ser queridas y protegidas por los chicos'). Cada ítem tiene seis alternativas de respuesta $(1=$ 'muy en desacuerdo'; $6=$ 'muy de acuerdo'). Los alfas de Cronbach fueron: $\mathrm{SH} \alpha=.85 ; \mathrm{SB} \alpha=.80$.

Estilos de crianza (Schaefer, 1965; versión española por Tur-Porcar, Mestre, \& Llorca, 2015)

Evalúa la actitud de padres y madres hacia la crianza según la perspectiva de hijos e hijas, a través de 38 ítems. Se presenta en tres alternativas: 'nunca', 'a veces' y 'siempre'. Consta de cuatro factores: (1) apoyo y comunicación, se refiere a la percepción de apoyo emocional y cariño (e.g., 'Le gusta hablar conmigo sobre las 
noticias'); (2) control psicológico, trata de un control intrusivo, y una evaluación negativa del hijo/hija (e.g., 'Quiere controlar todo lo que hago'); (3) permisividad, aborda la tendencia de los padres a permitir que los hijos/hijas hagan lo que quieran, ignorando las normas (e.g., 'Me deja salir siempre que quiero'); (4) negligencia, alude a la dejación de las responsabilidades como padres (e.g., 'Olvida darme las cosas que necesito'). Alfas de Cronbach: apoyo y comunicación $\alpha=.85$; control psicológico $\alpha=.73$; negligencia $\alpha=.71$; $\mathrm{y}$ permisividad $\alpha=.65$.

Conducta prosocial (Caprara \& Pastorelli, 1993; adaptación de Tur-Porcar, 2003)

A través de sus 15 ítems evalúa conductas de ayuda, confianza y simpatía. Se presenta mediante tres opciones de respuesta ('a menudo', 'a veces' o 'nunca'). Ejemplo de ítems: 'Intento ayudar a los otros/as', 'Soy amable'. Alfa de Cronbach .74.

Agresividad física y verbal (Caprara \& Pastorelli, 1993; versión española por Del Barrio, Moreno, \& López, 2001)

Evalúa la conducta de hacer daño a otros/as, física y verbal, como una forma leve de violencia (Furlong \& Smith, 1994). Consta de 20 ítems con tres alternativas de respuesta ('a menudo', 'a veces' o 'nunca'). Ejemplos de ítem: 'Hablo mal de mis compañeros/as', 'Pego a mis compañeros/as', 'Pongo zancadillas a mis compañeros/as', 'Insulto a mis compañeros/as'. Alfa de Cronbach .70.

La división de tareas domésticas se basó en tres ítems: (1) 'Mi madre realiza la mayoría de las tareas domésticas y mi padre sólo algunas'; (2) 'Mi padre tiene responsabilidades fuera de casa y mi madre se ocupa de las tareas domésticas'; (3) 'Entre hermanos del sexo opuesto, las chicas asumen más responsabilidad en la casa que los chicos'. Tipo de respuesta dicotómica.

\section{Resultados}

\section{Diferencias en función del sexo}

Para conocer las diferencias de sexo de los/las participantes se han realizado análisis de la varianza de un factor (ANOVA) con las variables $\mathrm{SH}, \mathrm{SB}$, conducta prosocial y agresividad, y los estilos de crianza de los padres (Tabla 1). Los ANOVAs confirmaron diferencias significativas en $\mathrm{SH}(F=269.53, p<.01$; $\left.\eta^{2}=.27\right)$ y en SB $\left(F=3.62, p<.05 ; \eta^{2}=.05\right)$. En ambos casos los chicos mostraron puntuaciones más elevadas. El tamaño del efecto fue grande para SH y pequeño para SB (Bray \& Maxwell, 1985).

En cuanto a las variables personales se observaron diferencias significativas en conducta prosocial $\left(F=33.68, p<.001 ; \eta^{2}=.04\right)$ (las chicas mostraron mayores puntuaciones) y en agresividad $\left(F=34.17, p<.001 ; \eta^{2}=.04\right)$ donde los chicos mostraron índices superiores. En los dos casos el tamaño del efecto fue medio. 
Tabla 1. Comparación de las medias de las variables estudiadas según el sexo.

\begin{tabular}{|c|c|c|c|c|c|c|}
\hline & \multicolumn{2}{|c|}{ Chicos } & \multicolumn{2}{|c|}{ Chicas } & \multirow[b]{2}{*}{$F$} & \multirow[b]{2}{*}{$\eta^{2}$} \\
\hline & $M$ & $D T$ & $M$ & $D T$ & & \\
\hline 1. Sexismo hostil & 3.79 & 1.09 & 2.55 & 0.95 & $269.53 * *$ & .27 \\
\hline 2. Sexismo benevolente & 4.27 & 1.08 & 4.11 & 1.15 & $3.62 *$ & .05 \\
\hline 3. Conducta prosocial & 2.43 & 0.29 & 2.55 & 0.26 & $33.69 * *$ & .04 \\
\hline 4. Agresividad física y verbal & 1.49 & 0.36 & 1.35 & 0.29 & $34.17 * *$ & .04 \\
\hline 5. Apoyo y comunicación ${ }^{(1)}$ & 4.52 & 1.31 & 4.48 & 1.21 & 0.04 & - \\
\hline 6. Control psicológico ${ }^{(2)}$ & 2.24 & 1.29 & 3.93 & 1.16 & $11.54 * *$ & .06 \\
\hline 7. Permisividad $^{(3)}$ & 3.23 & 1.73 & 3.01 & 1.67 & $4.62 *$ & .01 \\
\hline 8. Negligencia ${ }^{(4)}$ & 2.60 & 1.50 & 2.31 & 1.24 & $7.04 * *$ & .01 \\
\hline
\end{tabular}

Nota: **.01 (bilateral); *.05 (bilateral); ${ }^{(1)}$ Apoyo y comunicación (Madre x Padre); ${ }^{(2)}$ Control psicológico (Madre x Padre); ${ }^{(3)}$ Permisividad (Madre x Padre); ${ }^{(4)}$ Negligencia (Madre x Padre).

Sobre los estilos de crianza, los ANOVAs han confirmado que los chicos perciben mayor permisividad $\left(F=4.62, p<.05 ; \eta^{2}=.06\right)$, mayor negligencia $\left(F=7.04, p<.01 ; \eta^{2}=.01\right)$, y menor control psicológico $(F=11.54, p<.01$; $\left.\eta^{2}=.01\right)$ al compararlos con las chicas. En los tres casos el tamaño del efecto fue pequeño. El factor de apoyo y comunicación no obtuvo diferencias significativas entre chicos y chicas $(F=0.04, p>.05)$.

Un análisis descriptivo de los ítems relacionados con el reparto de tareas domésticas ha indicado que prácticamente la tercera parte de la muestra ha atribuido a la madre más responsabilidades en casa y al padre le ha otorgado el rol de colaborar. Las respuestas afirmativas (en porcentajes) según los ítems son: 'Mi madre realiza la mayoría de las tareas domésticas y mi padre sólo algunas' (71.7\%); al ítem 'Mi padre tiene responsabilidades fuera de casa y mi madre se ocupa de las tareas domésticas' (62.0\%); al ítem 'Entre hermanos del sexo opuesto, las chicas asumen más responsabilidad en la casa que los chicos' (47.3\%). En este último caso, las percepciones de los chicos y las chicas en el reparto de tareas domésticas entre adolescentes son más equilibradas.

\section{Análisis correlacionales entre las variables analizadas}

En SH, el análisis correlacional de Pearson ha mostrado, en chicos y chicas, relaciones positivas con un reparto desequilibrado de tareas domésticas, donde madres e hijas tienen mayor carga. Además, en chicos, el SH se ha relacionado con negligencia y permisividad en positivo y en las chicas con permisividad y control psicológico, en positivo. Asimismo, en chicos y chicas, han aparecido relaciones positivas entre $\mathrm{SH}$ y agresividad, y relaciones negativas entre $\mathrm{SH}$ y conducta prosocial (Tabla 2).

Respecto al SB, en chicos y chicas, han aparecido relaciones positivas con el reparto desigual de las tareas domésticas. También se ha relacionado con los factores de crianza de negligencia (en chicos) y control psicólogico y permisividad (en chicas) (Tabla 2). 


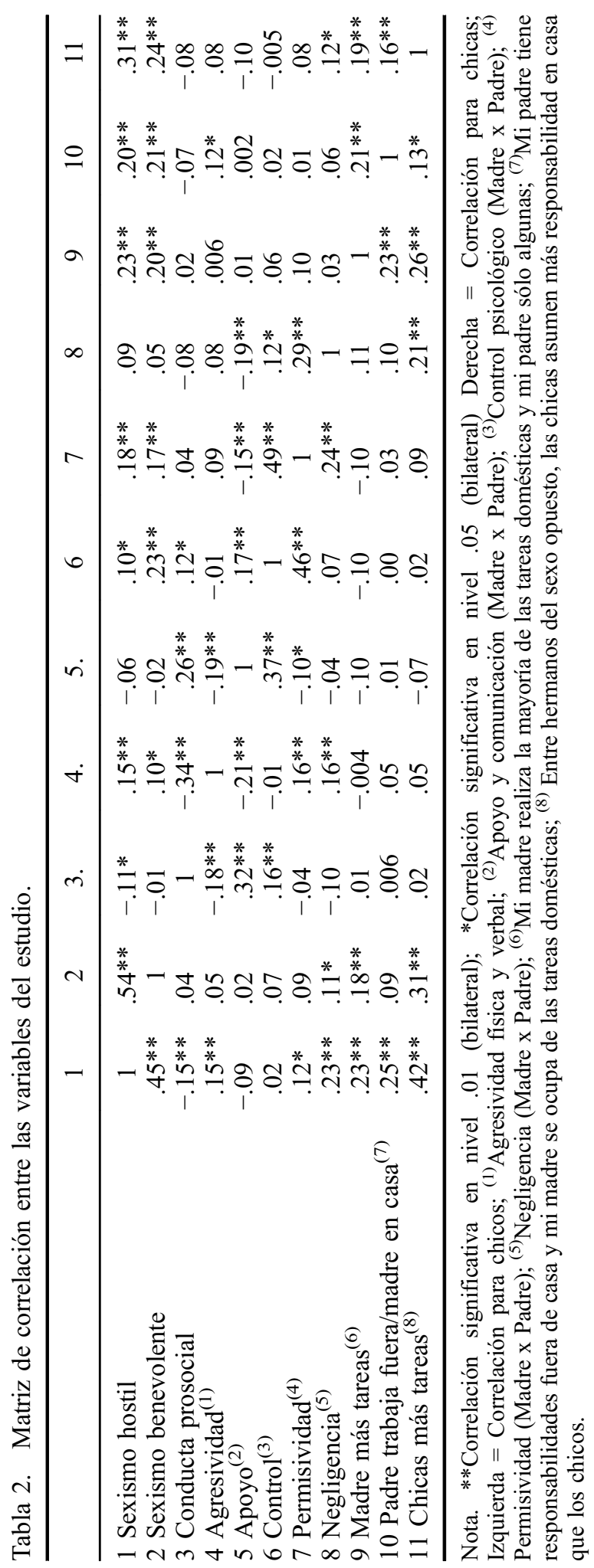




\section{Variables predictoras del SH y SB}

Finalmente, se han realizado cuatro regresiones lineales múltiples por pasos para analizar las variables predictoras de SH y SB en chicos y en chicas. Las variables dependientes son SH y SB. Las variables independientes son las variables del entorno familiar y las variables personales objeto de estudio. Los valores del factor de inflación de la varianza (FIV) (Tabla 3) se sitúan en torno a 1 en todos los casos (Kleinbaum, Kupper, \& Muller, 1988) indicando la inexistencia de problemas de colinealidad.

La Tabla 3 muestra que en el SH y SB el reparto de tareas domésticas tiene un peso mayor que las variables personales de prosocialidad y agresividad. Las variables predictoras en SH son: en chicos, se centran en el reparto de tareas domésticas y la negligencia $\left(R^{2}=.23\right)$; en chicas se centran en el reparto de tareas domésticas, en positivo, y en conducta prosocial, en negativo $\left(R^{2}=.17\right)$.

Tabla 3. Análisis de regresión lineal múltiple.

\begin{tabular}{|c|c|c|c|c|c|c|c|}
\hline & $R^{2}$ & $B$ & Error típico & Beta & $T$ & Sig. & $F I V$ \\
\hline \multicolumn{8}{|l|}{ Sexismo hostil } \\
\hline \multicolumn{8}{|l|}{ Chicos } \\
\hline Constante & & 1.54 & .33 & & 4.57 & .000 & \\
\hline Chicas más tareas ${ }^{(1)}$ & .19 & 0.84 & .13 & .38 & 6.35 & .000 & 1.06 \\
\hline Padre trabaja fuera/madre en casa ${ }^{(2)}$ & .21 & 0.35 & .13 & .15 & 2.60 & .010 & 1.01 \\
\hline Negligencia $^{(3)}$ & .23 & 0.34 & .14 & .14 & 2.34 & .020 & 1.04 \\
\hline \multicolumn{8}{|l|}{ Chicas } \\
\hline Constante & & 1.86 & .61 & & 3.03 & .003 & \\
\hline Chicas más tareas & .10 & 0.49 & .11 & .25 & 4.36 & .000 & 1.06 \\
\hline Madre más tareas ${ }^{(4)}$ & .13 & 0.35 & .12 & .16 & 2.83 & .005 & 1.06 \\
\hline Padre trabaja fuera/madre en casa & .16 & 0.30 & .11 & .15 & 2.64 & .009 & 1.05 \\
\hline Conducta prsocial & .17 & -0.42 & .20 & -.11 & -2.04 & .042 & 1.01 \\
\hline \multicolumn{8}{|l|}{ Sexismo benevolente } \\
\hline \multicolumn{8}{|l|}{ Chicos } \\
\hline Constante & & 3.21 & .21 & & 14.83 & .000 & \\
\hline Chicas más tareas & .09 & 0.61 & .13 & .28 & 4.46 & .000 & 1.04 \\
\hline Negligencia & .11 & 0.09 & .04 & .13 & 2.07 & .000 & 1.04 \\
\hline \multicolumn{8}{|l|}{ Chicas } \\
\hline Constante & & 1.73 & .38 & & 4.51 & .000 & \\
\hline Padre trabaja fuera/madre en casa & .07 & 0.49 & .13 & .21 & 3.70 & .000 & 1.05 \\
\hline Chicas más tareas & .11 & 0.41 & .13 & .18 & 3.12 & .002 & 1.05 \\
\hline Control psicológico ${ }^{(5)}$ & .14 & 0.14 & .05 & .16 & 2.89 & .004 & 1.00 \\
\hline Madre más tareas & .15 & 0.30 & .14 & .12 & 2.08 & .038 & 1.06 \\
\hline
\end{tabular}

Nota: ${ }^{(1)}$ Entre hermanos del sexo opuesto, las chicas asumen más responsabilidad en casa que los chicos; ${ }^{(2)} \mathrm{Mi}$ padre tiene responsabilidades fuera de casa y mi madre se ocupa de las tareas domésticas; ${ }^{(3)}$ Negligencia (Madre x Padre); ${ }^{(4)}$ Mi madre realiza la mayoría de las tareas domésticas y mi padre sólo algunas; ${ }^{(5)}$ Control psicológico (Madre x Padre). 
Respecto al SB, en chicos, las variables que explican sus actitudes sexistas están relacionadas con el reparto de tareas domésticas y la negligencia, todas en positivo $\left(R^{2}=.11\right)$. En chicas, las variables predictoras continúan siendo las relacionadas con el reparto de tareas más el control psicológico, todas en positivo. Estas variables explican el $15.5 \%$ de la varianza $\left(R^{2}=.15\right)$.

\section{Discusión}

El objetivo central de este estudio ha sido analizar el peso de los factores del entorno familiar (reparto de tareas domésticas y estilos de crianza) y los factores personales de agresividad y conducta prosocial en la predicción del SH y SB en chicos y chicas en la adolescencia temprana.

Los resultados mostraron que tanto el SH como el SB están relacionados con una distribución desigual de las tareas domésticas, soportadas fundamentalmente por las mujeres. Asimismo, el sexismo también se ha relacionado con una crianza más punitiva como el control psicológico y la negligencia, además de la permisividad (Hipótesis 2). Por tanto, el entorno familiar, a través de la distribución de tareas domésticas, unido a una crianza más punitiva (control psicológico y negligencia) han apoyado actitudes sexistas hostiles y benevolentes (Hipótesis 4).

Los modelos parentales son visibles a los hijos e hijas. Padres y madres mandan mensajes y piden colaboración para realizar las tareas domésticas, de ahí que sus demandas pueden ayudar a consolidar los roles tradicionales de género (Wood \& Eagly, 2010).

El análisis muestra a los chicos adolescentes más sexistas (hostiles y benevolentes) que las chicas de su misma edad (Montañés et al., 2015; Rodríguez et al., 2010) (Hipótesis 1). Ambos tipos de sexismo refuerzan las estructuras sociales desequilibradas por razón del género (Glick \& Hilt, 2000; Wood \& Eagly, 2010). Estos resultados corroboraron que el reparto desigual de tareas domésticas puede contribuir a perpetuar las relaciones asimétricas, que tienen su origen en una estructura patriarcal basada en el reparto de roles (Chen et al., 2009). Los resultados aquí obtenidos son consistentes con otros estudios realizados con adolescentes estadounidenses, suecos y españoles (De Lemus et al., 2008; Zakrisson, Anderzén, Lenell, \& Sandelin, 2012). Además, al favorecer a los hombres se les está dotando de un poder sobre las mujeres (De Lemus et al., 2008), que puede llegar a tener efectos contraproducentes sobre la población y tener un impacto negativo en la formación y el desarrollo profesional de las mujeres (Fisher \& Anderson, 2012).

Por otra parte, aparecen relaciones positivas del SH y SB con la agresividad (Ovejero et al., 2013), y negativas del SH con la conducta prosocial, en chicos y chicas. Sin embargo, los chicos puntuaron más alto en agresividad, mientras que las chicas puntuaron más alto en conducta prosocial (Hipótesis 1). De esta manera, las chicas mostraron mejores índices en atribuciones relacionadas con la feminidad (e.g., comprensión o altruismo). Estas diferencias reflejan la dualidad de la existencia humana, al otorgar a las chicas atributos comunales y a los chicos agénticos (Wood \& Eagly, 2010). Con todo, consideramos que es positivo obtener 
puntuaciones elevadas en conducta prosocial, dado su carácter protector (Eisenberg et al., 2005), y que habrían de ser semejantes en ambos sexos. Estos resultados están en la línea de otros estudios que abordan diferencias de sexo en conducta prosocial (Carlo et al., 2010). Asimismo, la conducta prosocial ha resultado ser predictora del $\mathrm{SH}$ en las chicas actuando de forma negativa, es decir, protectora del $\mathrm{SH}$.

Respecto al reparto de tareas domésticas, casi las tres cuartas partes de la población afirman que las madres asumen una mayor carga. Entre los y las adolescentes este porcentaje disminuye a la mitad. La disminución del porcentaje en la adolescencia puede reflejar la evolución de la sociedad española hacia un modelo más igualitario (Gartzia \& López-Zafra, 2014). Estas observaciones apoyan la doble jornada laboral de las mujeres, es decir, en su lugar de trabajo y en casa (esfera pública/privada).

Además, el reparto desequilibrado de tareas domésticas, asignadas a madres e hijas, tienen un gran peso en la predicción de $\mathrm{SH}$ y $\mathrm{SB}$, tanto en chicos como en chicas (Hipótesis 4). Por lo tanto, esta situación refuerza la desigualdad social basada en el género. Los resultados son consistentes con otros estudios que muestran a las mujeres españolas con una fuerte carga doméstica, llegando a duplicar y triplicar el tiempo dedicado a estas tareas, comparado con el tiempo dedicado por los hombres (Instituto de la Mujer, 2013). Es necesario, por tanto, estimular el reparto equilibrado de las responsabilidades familiares para romper con estereotipos de género, tan unidos al mantenimiento del sexismo. Aunque el SB es aparentemente más conciliador, también es más eficaz para perpetuar diferencias de género (Delacollette, Dumont, Sarlet, \& Dardenne, 2013).

Un análisis transcultural indica que la situación entre adolescentes españoles no difiere mucho de otras culturas. La división equilibrada/desequilibrada de tareas domésticas facilita la trasmisión de modelos entre adolescentes, dando lugar a actitudes sexistas o igualitarias en diferentes países como Estados Unidos o Canadá (Fisher \& Anderson, 2012; Williams et al., 2013).

Por lo que se refiere a los estilos de crianza, el SH está relacionado con una crianza más punitiva (control psicológico y negligencia) (Hipótesis 2). La crianza punitiva promueve poco cariño y poca comunicación (Barnhart et al., 2013). Estos resultados refuerzan otros hallazgos obtenidos por Garaigordobil y Aliri (2012), quienes encontraron que un estilo de crianza indulgente/permisivo promueve menos actitudes sexistas. En nuestra investigación, el control psicológico es predictor de SB en las chicas y la negligencia es predictora del SH y SB entre los chicos (Hipótesis 4).

Los resultados confirman que los roles tradicionales y la disciplina familiar tienen mayor relevancia en la predicción de actitudes sexistas que las variables personales como la agresividad y la conducta prosocial (Hipótesis 4). En otras palabras, la forma de actuar de ambos padres promueve actitudes sexistas. Asimismo, los factores de control psicológico y negligencia de ambos padres predicen positivamente el SB en la adolescencia.

Los resultados indican, además, la complejidad del SB. Sus matices positivos le otorgan cierta aceptación social, incluso entre las mujeres, que buscan de su 
protección. A pesar de esta amplia aceptación, SB es una forma de sexismo que perpetúa la desigualdad social (Becker \& Swim, 2011).

En síntesis cabe suponer que la dinámica interna familiar y los estilos de crianza se encuentran interrelacionados, de tal forma que un estilo de familia más tradicional tiende a ser más autoritario. La crianza autoritaria y más punitiva impulsa unas reglas de convivencia y de comunicación unidireccional, de padres a hijos. Estos modelos son propensos a mantener la distribución tradicional de roles en razón del género. A los varones se les asignan roles activos hacia fuera del hogar para garantizar recursos económicos, mientras que esperan de las mujeres roles más comunales, de esposas y madres (Wood \& Eagly, 2010). Además, el SB de las madres puede predecir el SB de las hijas (Montañés et al., 2012).

Por otra parte, situaciones semejantes se han observado en un estudio reciente desarrollado en Nueva Orleans (USA), Williams et al. (2013) mostraron que las chicas cuyos padres compartían equilibradamente las tareas domésticas con sus parejas fueron menos propensas a tener actitudes sexistas.

Los resultados muestran la necesidad de organizar talleres orientados a las familias que expliquen el valor de la co-responsabilidad familiar. Es necesario dotar de recursos que potencien la co-educación desde la perspectiva de género y estimulen un reparto equitativo de las tareas domésticas y se vaya destruyendo la dualidad de la existencia humana. Con esto contribuiremos a que chicos y chicas desarrollen todo su potencial sin sufrir los límites de los estereotipos de género. Además, la eficacia de las intervenciones para reducir las actitudes sexistas podría mejorarse formando a las familias y promoviendo formas de disciplina más inductivas y menos punitivas.

Este estudio tiene algunas limitaciones. Primera, los datos se recogieron mediante autoinformes de los adolescentes. En estudios futuros deberían comparar las actitudes sexistas de los adolescentes con las actitudes de sus padres. Esta comparación puede mostrar el grado de afinidad entre padres e hijos, además de mostrar la evolución de las actitudes en la adolescencia hacia este fenómeno social.

Segunda, este estudio se ha centrado en la adolescencia temprana. Estudios futuros podrían analizar el sexismo en diferentes periodos de la adolescencia y el sexismo en relación con el entorno escolar y las relaciones sociales con sus pares. Por ejemplo, ¿el abuso y la victimización por los pares afectan a las actitudes sexistas adolescentes? ¿Tiene el curriculum académico alguna relación con las actitudes sexistas? ¿Las actitudes sexistas promueven la elección de carreras más asistenciales y feminizadas en las chicas adolescentes?

Tercera, estudios posteriores deberían observar las actitudes sexistas entre pares. Este conocimiento es relevante para entender el sexismo entre chicos y chicas. Además, otros factores personales, como la empatía o los valores humanos, son relevantes y podrían explicar también las actitudes sexistas. Somos conscientes que estudiar el desarrollo de $\mathrm{SH}$ y SB tiene varias implicaciones para la reducción de las desigualdades de género (De Lemus et al., 2008), no 
obstante, un cambio de actitud puede ser insuficiente para erradicar la desigualdad de género debido al sexismo recurrente e inconsciente difícil de evitar.

Finalmente, otra limitación se refiere al carácter transversal de la investigación que no facilita establecer relaciones de causalidad. Parece lógico, y los resultados van en esta línea, que una desigual distribución de tareas y los estilos de crianza, es decir, factores ambientales, son fundamentales en el desarrollo de las actitudes sexistas en la adolescencia temprana.

\section{Acknowledgements / Agradecimientos}

R\&D Project Research Groups of Excellence (PROMETEO 2011/009), Generalitat Valenciana; and R\&D Project Network of Excellence ISIC/2013/001, Generalitat Valenciana. / Proyecto I+D Grupos de Investigación de Excelencia (PROMETEO 2011/ 009), Generalitat Valenciana; y Proyecto I+D Red de Excelencia ISIC/2013/001, Generalitat Valenciana.

\section{Disclosure statement}

No potential conflict of interest was reported by the authors. / Los autores no han referido ningsún potencial conflicto de interés en relación con este artículo.

\section{References / Referencias}

Bandura, A. (2011). A social cognitive perspective on positive psychology. Revista de Psicología Social, 26, 7-20. doi:10.1174/021347411794078444

Barnhart, C. M., Raval, V. V., Jansari, A., \& Raval, P. H. (2013). Perceptions of parenting style among college students in India and the United States. Journal of Child and Family Studies, 22, 684-693. doi:10.1007/s10826-012-9621-1

Becker, J. C., \& Swim, J. K. (2011). Seeing the unseen: Attention to daily encounters with sexism as way to reduce sexist beliefs. Psychology of Women Quarterly, 35, 227-242. doi:10.1177/0361684310397509

Becker, J. C., \& Wright, S. C. (2011). Yet another dark side of chivalry: Benevolent sexism undermines and hostile sexism motivates collective action for social change. Journal of Personality and Social Psychology, 101, 62-77. doi:10.1037/a0022615

Bergin, C., Talley, S., \& Hamer, L. (2003). Prosocial behaviors of young adolescents: A focus group study. Journal of Adolescence, 26, 13-32. doi:10.1016/S0140-1971(02) 00112-4

Björkqvist, K. (1994). Sex differences in physical, verbal and indirect aggression: A review of recent research. Sex Roles, 30, 177-188. doi:10.1007/BF01420988

Brandt, M. J. (2011). Sexism and gender inequality across 57 societies. Psychological Science, 22, 1413-1418. doi:10.1177/0956797611420445

Bray, J., \& Maxwell, S. (1985). Multivariate analysis of variance (Quantitative applications in the social sciences). Beverly Hills: Sage Publications, Inc.

Buchanan, N. T., Settles, I. H., Hall, A. T., \& O’Connor, R. C. (2014). A review of organizational strategies for reducing sexual harassment: Insights from the U. S. military. Journal of Social Issues, 70, 687-702. doi:10.1111/josi.12086

Campbell, A. (2006). Sex differences in direct aggression: What are the psychological mediators? Aggression and Violent Behavior, 11, 237-264. doi:10.1016/j. avb.2005.09.002 
Caprara, G. V., \& Pastorelli, C. (1993). Early emotional instability, prosocial behavior, and aggression: Some methodological aspects. European Journal of Personality, 7, 19-36. doi:10.1002/per.2410070103

Carlo, G., Mestre, M. V., Samper, P., Tur, A., \& Armenta, B. (2010). Feelings or cognitions? Moral cognitions and emotions as longitudinal predictors of prosocial and aggressive behaviors. Personality and Individual Differences, 48, 872-877. doi:10.1016/j.paid.2010.02.010

Chen, Z., Fiske, S. T., \& Lee, T. L. (2009). Ambivalent sexism and power-related genderrole ideology in marriage. Sex Roles, 60, 765-778. doi:10.1007/s11199-009-9585-9

De Lemus, S., Castillo, M., Moya, M., Padilla, J. L., \& Ryan, E. (2008). Elaboración y validación del Inventario de Sexismo Ambivalente para Adolescentes. International Journal of Clinical and Health Psychology, 8, 537-562.

De Lemus, S., Moya, M., \& Glick, P. (2010). When contact correlates with prejudice: Adolescents' romantic relationship experience predicts greater benevolent sexism in boys and hostile sexism in girls. Sex Roles, 63, 214-225. doi:10.1007/s11199-0109786-2

Del Barrio, V., Moreno, C., \& López, R. (2001). Evaluación de la agresión e inestabilidad emocional en niños españoles y su relación con la depresión. Clínica y Salud, 12, 33-50.

Delacollette, N., Dumont, M., Sarlet, A., \& Dardenne, B. (2013). Benevolent sexism, men's advantages and the prescription of warmth to women. Sex Roles, 68, 296-310. doi:10.1007/s11199-012-0232-5

Eisenberg, N., Zhou, Q., Spinrad, T. L., Valiente, C., Fabes, R., \& Liew, J. (2005). Relations among positive parenting, children's effortful control, and externalizing problems: A three-wave longitudinal study. Child Development, 76, 055-1071. doi:10.1111/j.1467-8624.2005.00897.x

Expósito, F., Herrera, M. C., Moya, M., \& Glick, P. (2010). Don't rock the boat: Women's benevolent sexism predicts fears of marital violence. Psychology of Women Quarterly, 34, 36-42. doi:10.1111/j.1471-6402.2009.01539.x

Fisher, J., \& Anderson, V. N. (2012). Gender role attitudes and characteristics of stay-athome and employed fathers. Psychology of Men \& Masculinity, 13, 16-31. doi: $10.1037 / \mathrm{a} 0024359$

Furlong, M. J., \& Smith, D. C. (Eds.). (1994). Anger, hostility, and aggression in youth: Assessment, prevention, and intervention strategies for youth. New York, NY: John Wiley. doi:10.1002/1520-6807(199410)31:43.0.CO;2-2

Garaigordobil, M., \& Aliri, J. (2012). Parental socialization styles, parents educational level, and sexist attitudes in adolescence. The Spanish Journal of Psychology, 15, 592-603. doi:10.5209/rev_SJOP.2012.v15.n2.38870

Gartzia, L., \& López-Zafra, E. (2014). Gender research in Spanish psychology: An overview for international readers. Sex Roles, 70, 445-456. doi:10.1007/s11199-014-0380-x

Glick, P., \& Fiske, S. (1996). The ambivalent sexism inventory: Differentiating hostile and benevolent sexism. Journal of Personality and Social Psychology, 70, 491-512. doi:10.1037/0022-3514.70.3.491

Glick, P., \& Hilt, L. (2000). From combative children to ambivalent adults: The development of gender prejudice. In T. Eckes \& M. Trautner (Eds.), Developmental social psychology of gender (pp. 243-272). Mahwah, NJ: Erlbaum.

Glick, P., Lameiras, M., Fiske, S. T., Eckes, T., Masser, B., Volpato, C., ... Glick, P. (2004). Bad but bold: Ambivalent attitudes toward men predict gender inequality in 16 nations. Journal of Personality and Social Psychology, 86, 713-728. doi:10.1037/ 0022-3514.86.5.713

Hammond, M. D., \& Sibley, C. G. (2011). Why are benevolent sexists happier? Sex Roles, 65, 332-343. doi:10.1007/s11199-011-0017-2

Hammond, M. D., Sibley, C. G., \& Overall, N. C. (2014). The allure of sexism: Psychological entitlement fosters women's endorsement of benevolent sexism over 
time. Social Psychological and Personality Science, 5, 422-429. doi:10.1177/ 1948550613506124

Hart, J., Hung, J. A., Glick, P., \& Dinero, R. E. (2012). He loves her, he loves her not: Attachment style as a personality antecedent to men's ambivalent sexism. Personality and Social Psychology Bulletin, 38, 1495-1505. doi:10.1177/0146167212454177

INJUVE. (2012a). Cambios y persistencias en la igualdad de género de los y las jóvenes en España (1990-2010). Madrid: Ministerio de Sanidad, Servicios Sociales e Igualdad, Gobierno de España.

INJUVE. (2012b). Informe Juventud en España 2012. Ministerio de Sanidad, Servicios sociales e Igualdad. Retrieved from http://www.injuve.es/sites/default/files/2013/26/ publicaciones/IJE2012_0.pdf

Instituto de la Mujer. (2013). Mujeres en cifras. Boletín estadístico. Retrieved from http:// www.inmujer.gob.es/estadisticas/boletinEstadistico/docs/Boletin3Marzo2013.pdf

Kleinbaum, D. G., Kupper, L. L., \& Muller, K. E. (1988). Applied regressions analysis and other multivariate methods (2nd ed.). Belmont, CA: Wadsworth Publishing Company. doi:10.1080/00401706.1989.10488486

Lee, T. L., Fiske, S. T., \& Glick, P. (2010). Next gen ambivalent sexism: Converging correlates, causality in context, and converse causality, an introduction to the special issue. Sex Roles, 62, 395-404. doi:10.1007/s11199-010-9747-9

López-Zafra, E., \& García-Retamero, R. (2012). Do gender stereotypes change? The dynamic of gender stereotypes in Spain. Journal of Gender Studies, 21, 169-183. doi:10.1080/09589236.2012.661580

Montañés, P., De Lemus, S., Bohner, G., Megías, J. L., Moya, M., \& Garcia-Retamero, R. (2012). Intergenerational transmission of benevolent sexism from mothers to daughters and its relation to daughters' academic performance goals. Sex Roles, 66, 468478. doi:10.1007/s11199-011-0116-0

Montañés, P., Megías, J. L., De Lemus, S., \& Moya, M. (2015). Influence of early romantic relationships on adolescents' sexism/ Sexismo en la adolescencia: Influencia de las primeras relaciones de pareja. Revista de Psicología Social, 30, 219-240. doi:10.1080/ 21711976.2015.1016756

Napier, J. L., Thorisdottir, H., \& Jost, J. T. (2010). The joy of sexism? A multinational investigation of hostile and benevolent justifications for gender inequality and their relation to subjective well-being. Sex Roles, 62, 405-419. doi:10.1007/s11199-0099712-7

Ovejero, A., Yubero, S., Larrañaga, E., \& Navarro, R. (2013). Sexismo y comportamiento de acoso escolar en adolescentes. Psicología Conductual, 21, 157-171.

Poeschl, G., Pinto, I., Múrias, C., Silva, A., \& Ribeiro, R. (2006). Representations of family practices, belief in sex differences and sexism. Sex Roles, 55, 111-121. doi:10.1007/s11199-006-9062-7

Rodríguez, Y., Lameiras, M., Carrera, M. V., \& Faílde, J. M. (2010). Evaluación de las actitudes sexistas en estudiantes españoles/as de educación secundaria obligatoria. Psychologia: Avances de la Disciplina, 4, 11-24.

Schaefer, E. S. (1965). Children's reports of parental behavior: An inventory. Child Development, 36, 413-424. doi:10.2307/1126465

Shnabel, N., Bar-Anan, Y., Kende, A., Bareket, O., \& Lazar, Y. (2016). Help to perpetuate traditional gender roles: Benevolent sexism increases engagement in dependencyoriented cross-gender helping. Journal of Personality and Social Psychology, 110, 55-75. doi:http://dx.doi.org/10.1037/pspi0000037

Sidanius, J., \& Pratto, F. (2004). Social dominance theory: A new synthesis. In J. Jost \& J. Sidanius (Eds.), Political psychology (pp. 315-332). Nueva York: Psychology Press. doi: 10.1017/CBO9781139175043.002 
Tur-Porcar, A. (2003). Conducta agresiva y prosocial en relación con el temperamento y hábitos de crianza en niños y adolescentes. (Doctoral Dissertation). Universitat de València. Retrieved from https://www.educacion.es/teseo/mostrarRef.do?ref=289449

Tur-Porcar, A., Mestre, M. V., \& Llorca, A. (2015). Parenting: Psychometric analysis of two studies in Spanish population. Anuario de Psicologia/The UB Journal of Psychology, 45, 347-359.

Tur-Porcar, A., Mestre, M. V., Samper, P., \& Malonda, E. (2012). Crianza y agresividad de los menores: ¿Es diferente la influencia del padre y de la madre? Psicothema, 24, 284-288.

Valiente, C., Eisenberg, N., Haugen, R. G., Spinrad, T. L., Hofer, C., Liew, J., \& Kupfer, A. (2011). Children's effortful control and academic achievement: Mediation through social functioning. Early Education \& Development, 22, 411-433. doi:10.1080/ 10409289.2010.505259

Williams, M., Park, B., Schmader, T., \& Cheryan, S. (2013). Charting new routes for women at work: Looking to the home and classroom. Work presented by Society for Personality and Social Psychology, New Orleans.

Wood, W., \& Eagly, A. H. (2010). Gender. In S. T. Fiske, D. T. Gilbert, \& G. Lindzey (Eds.), Handbook of social psychology (Vol. 1, 5th ed., pp. 629-667). New York, NY: Wiley.

Yamawaki, N., Ostenson, J., \& Brown, C. R. (2009). The functions of gender role traditionality, ambivalent sexism, injury, and frequency of assault on domestic violence perception: A study between Japanese and American college students. Violence Against Women, 15, 1126-1142. doi:10.1177/1077801209340758

Zakrisson, I., Anderzén, M., Lenell, F., \& Sandelin, H. (2012). Ambivalent sexism: A tool for understanding and improving gender relations in organizations. Scandinavian Journal of Psychology, 53, 64-70. doi:10.1111/j.1467-9450.2011.00900.x 